\title{
FDA hydrolysis and resazurin reduction as a measure of microbial activity in sediments from the south-east Atlantic
}

\author{
R. Gumprecht, H. Gerlach \& A. Nehrkorn \\ Universität Bremen, Abt. Mikrobiologie, FB 2; D-28359 Bremen, Germany
}

\begin{abstract}
Esterase and dehydrogenase activities were determined in depth profiles of sediments from the south-east Atlantic using fluorometric methods. The sensitivity of both methods was sufficient to record enzymatic activities in deep-sea clay and foraminiferous sand. Depending on water depth and location, significant differences between the depth profiles of enzyme activities could be determined. They appear to be dependent on the organic-matter input from sedimentation. Conclusions about the mode of microbial degradation of organic matter (oxic, anoxic, type of electron acceptors) are possible, using suitable chemical parameters. Under oxic conditions $\left(E_{h}>200 \mathrm{mv}\right)$ it was possible (using the method developed for dehydrogenase activities) to determine depth profiles similar to those of the esterase activities. Under suboxic or anoxic conditions, an appropriate separation between biological (dehydrogenase activity) and chemical resazurin reduction was not possible.
\end{abstract}

\section{INTRODUCTION}

In oligotrophic biotopes, such as sediments in the deep-sea, sensitive methods for recording low-level microbial activities are necessary. To minimize alteration of the samples, methods are required which allow rapid treatment after sampling, and short analysis times. Both requirements are met by the determination of enzymatic activities by means of fluorescence spectrometry.

Dehydrogenases and esterases are promising enzyme groups for determining total microbial activities, because of their importance for microbial metabolism and the multitude of reactions they catalyze.

Dehydrogenases belong to the main group of oxidoreductases. On a cellular level they play a decisive role in both catabolism and anabolism. As integral components of intact cells (intracellular enzymes) (Ladd, 1978), they oxidize endogenous substrates by dehydrogenation, e.g. during glycolysis and in the tricarboxylic acid cycle, and channel substrate hydrogen in membrane-bound electron-transport chains. Dehydrogenases therefore reflect almost the total spectrum of oxidative microbial activities (Ladd, 1978) and fulfil a significant role in the oxidation of organic matter (Skujins, 1975).

The determination of dehydrogenase activity as a parameter for microbial activity has been frequently used in microbial ecology, especially in soil microbiology (cf. Alef, 1991). For spectrophotometric determinations, triphenyltetrazolium chloride (TTC) and iodonitrotetrazolium violet (INT) usually serve as electron acceptors. The photometric 
determination of resazurin reduction as a measure for dehydrogenase activity has been used for sediments (Liu \& Strachan, 1979; Peroni \& Rossi, 1986), to check bacteriological quality of seafood (Reddy et al., 1990; Kuemmerlin, 1982) and to control toxicity of activated sludges (Liu, 1981, 1983; Ewald et al., 1987; Ewald, 1989). Guilbault \& Kramer $(1964,1965)$ described a fluorometric method based on resazurin reduction by pure enzymes.

The ester-cleaving enzymes are a subgroup of the maingroup hydrolases. A multitude of enzymes - esterases (e.g. lipases, phosphatases) and nucleases - are capable of cleaving ester bonds. Fluorescein esters, including fluorescein diacetate (FDA), were found to be hydrolysed by lipases and acylase, but not by acetylcholinesterase (Guilbault \& Kramer, 1966). Esterases can be found extracellularly as well as intracellularly. The substrate FDA can be transported across cell membranes and deacetylated by nonspecific esterases (Chrzanowski et al., 1984).

The determination of FDA hydrolysis has been used to estimate microbial biomass on coniferous needles (Swisher \& Carroll, 1980), to measure total microbial activity in soil and litter (Schnürer \& Rosswall, 1982), microbial activities in water samples (HolzapfelPschorn et al., 1987), and hydrolytic activity associated with biogenic structures in deepsea sediments (Köster et al., 1991). According to Meyer-Reil (1991), however, it is not possible to distinguish between extra- and intracellular hydrolysis.

For our own investigations, dehydrogenase and esterase activities in sediments from the south-east Atlantic were examined within the scope of the DFG-promoted (Deutsche Forschungsgemeinschaft) Sonderforschungsbereich (SFB) 261 of the University of Bremen ("Der Südatlantik im Spätquartär: Rekonstruktion von Stoffhaushalt und Strom. systemen"). The results presented here were obtained on the "Meteor"-cruise M 20-2 (1991/1992, Abidjan-Dakar).

\section{MATERIAL AND METHODS}

\section{Sediments}

Sediment samples were investigated at, among other places, the Stations GeoB 1711, 1719,1721 (continental slope in front of Namibia), GeoB 1724 (deep-sea plain of the Cape Basin) and GeoB 1726 (southern Walvis Ridge) (compare Fig. 1). The exact locations and water depths are given in Table 1.

Table 1. Locations and water depths of the examined GeoB Stations

\begin{tabular}{|lccc|}
\hline GeoB Station & $\sim$ Wd $[\mathrm{m}]$ & Latitude & Longitude \\
\hline 1711 & 2000 & $23^{\circ} 19^{\prime} \mathrm{S}$ & $12^{\circ} 23^{\prime} \mathrm{E}$ \\
1719 & 1000 & $28^{\circ} 56^{\prime} \mathrm{S}$ & $14^{\circ} 10^{\prime} \mathrm{E}$ \\
1721 & 3000 & $29^{\circ} 10^{\prime} \mathrm{S}$ & $13^{\circ} \mathrm{O5^{ \prime } \mathrm { E }}$ \\
1724 & 5100 & $29^{\circ} 58^{\prime} \mathrm{S}$ & $08^{\circ} 03^{\prime} \mathrm{E}$ \\
1726 & 1000 & $30^{\circ} 16^{\prime} \mathrm{S}$ & $03^{\circ} 16^{\prime} \mathrm{E}$ \\
Wd = water depth & $\mathrm{S}=$ south $\mathrm{E}=$ east & & \\
\hline
\end{tabular}




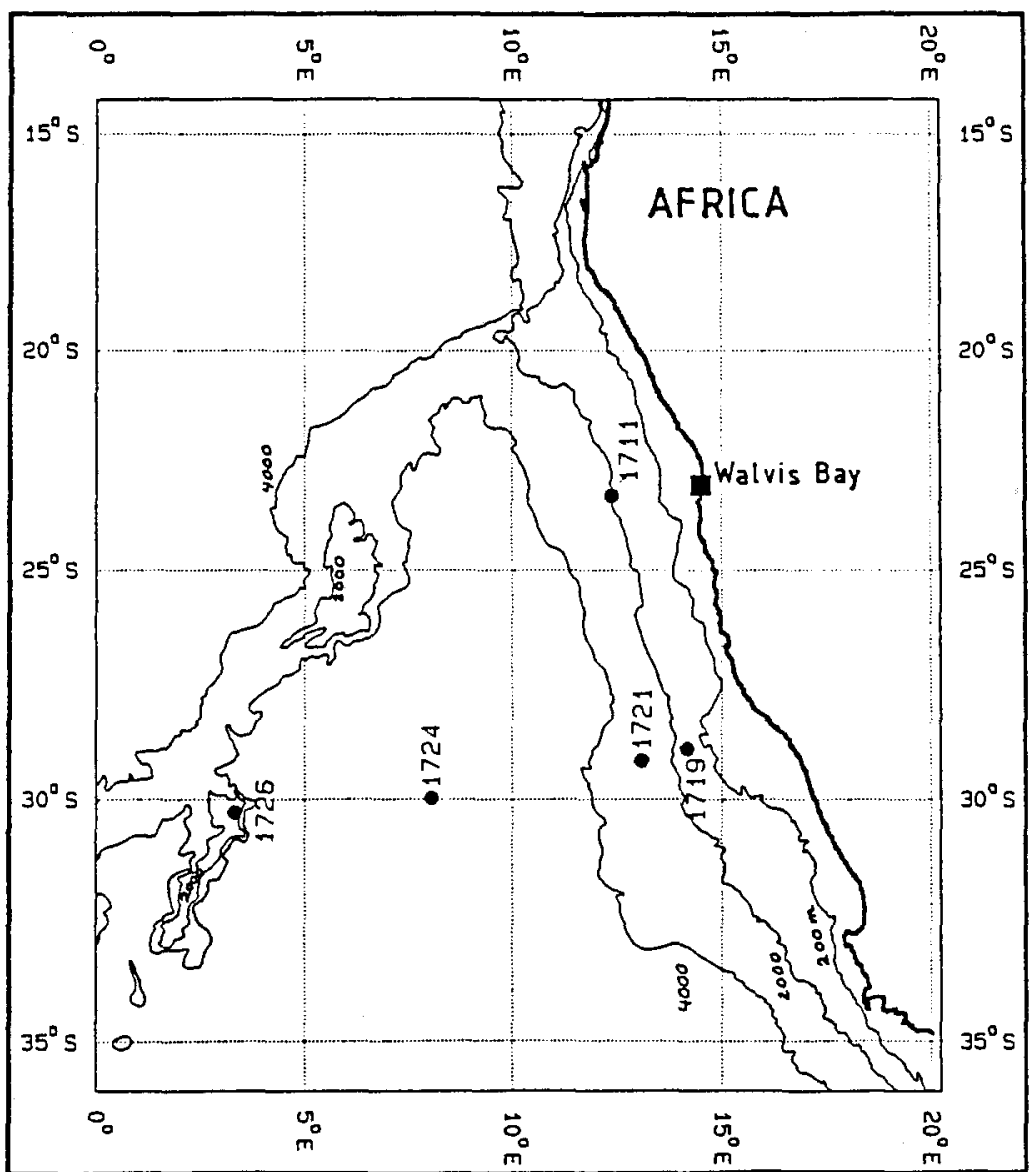

Fig. 1. Sampling sites for the determination of enzymatic activities - "Meteor" cruise M 20/2

\section{Enzymatic activities}

Sediment samples were taken with syringes from multi-corers, box-corers and gravity-corers. Enzymatic activities were determined as rapidly as possible after sampling (within $24 \mathrm{~h}$ ) on ship-board. Sediment suspensions were made by mixing sediment and sterile filtered sea-water in the ratio $1: 4(\mathrm{v}: \mathrm{v})$.

\section{Esterase activity}

The determination of esterase activity is based on the hydrolysis of fluorescein diacetate (FDA) by nonspecific esterases and the fluorometric determination of the released fluorescein. The method was conducted, in the main, as described by Köster (1992). $25 \mu \mathrm{l}$ FDA solution ( $4.8 \mathrm{mM}$ ) were added to $1 \mathrm{ml}$ of sediment suspension. The suspensions were incubated for 30 and $90 \mathrm{~min}$. After addition of $3 \mathrm{ml}$ sterile filtered seawater and centrifugation ( $3000 \mathrm{~g}$ for $10 \mathrm{~min}$ ), the fluorescence of the supernatants was 
determined immediately (ex 480 , em $513 \mathrm{~nm}$; slit maximum $5 \mathrm{~nm}$ ), setting a $5 \mu \mathrm{M}$ fluorescein standard to 100 fluorescence units. Since FDA is subject to spontaneous hydrolysis (depending on the environmental conditions), controls with sediment suspension were autoclaved and treated in like manner. All work was done at $4{ }^{\circ} \mathrm{C}$. The enzyme activity was calculated from the nmol fluorescein formed in the period 30 to $90 \mathrm{~min}$ after subtraction of the control values. The FDA hydrolysis was found to be linear up to 120 min of incubation, depending on the biological activity of the samples.

\section{Dehydrogenase activity}

The determination of dehydrogenase activity is based on the enzymatic reduction of resazurin $\left(E_{h}+0.05 \mathrm{v}\right)$ to resorufin in the course of the dehydrogenation of endogenous substrates and the fluorometric determination of the product resorufin (compare Guilbault \& Kramer, 1965; Ewald, 1989).

$50 \mu \mathrm{l}$ resazurin solution $\left(1.6 \times 10^{-4} \mathrm{M}\right)$ were added to $1 \mathrm{ml}$ of sediment suspension. The mixture was incubated for $6 \mathrm{~h}$ at $20^{\circ} \mathrm{C}$. After addition of $0.5 \mathrm{ml}$ borate buffer $(0.2 \mathrm{M}$; ph 10.6), $3 \mathrm{ml}$ sterile filtered sea-water and centrifugation $(3000 \mathrm{~g}$ for $10 \mathrm{~min})$, the fluorescence of the supernatants was determined (ex 560 , em $590 \mathrm{~nm}$; slit maximum $5 \mathrm{~nm}$ ) setting a $1 \mu \mathrm{M}$ resorufin standard to 100 fluorescence units. Controls were treated with $25 \mu \mathrm{l} 25 \%$ ethylmercurithiosalicyl acid to determine the abiotic resazurin reduction. Autoclaving leads to underestimation of the abiotic reduction, probably because it changes the chemical properties of the samples too much. The enzyme activity was calculated from the nmol resorufin formed in $1 \mathrm{~h}$ after subtraction of the control values. The resazurin reduction was found to be linear up to $8 \mathrm{~h}$ of incubation, depending on the sediment properties.

\section{RESULTS AND DISCUSSION}

First, it should be noted that we determined enzymatic capacities with the methods described above, not in situ activities. Nevertheless, the enzymatic activities are thought to reflect the enzyme concentration present in the original sample, if a loss in activity and microbial proliferation is prevented. Furthermore, the enzymatic activities (especially in the upper sediment layers) can be attributed not only to microbial cells, but also to plant and animal cells. It was found by Köster et al. (1991), that the benthic fauna can contribute substantially to the measured esterase activities down to a sediment depth of $40 \mathrm{~cm}$. It is not known if this is also the case in greater depths. Wetzel (1981) has shown that bioturbation only influenced the first $0.5 \mathrm{~m}$ of upwelling sediments from the northwest African continental slope. In all sediment layers, the possible contribution of accumulated extracellular enzymes (e.g. esterases) to the measured activities should not be disregarded. Enzymes can be stabilized, especially by association with humic matter, and persist in this way, even for geological periods (cf. Skujins, 1975).

Figure 2 shows two different depth profiles of esterase activities from the Stations GeoB 1721 and GeoB 1711. At Station 1721, high esterase activities are limited to the upper sediment decimeter. Below $10 \mathrm{~cm}$, only an increase in activity at $90 \mathrm{~cm}$ is noticeable. At this depth, a gradient change in the phosphate content of the pore water (derived from concentration profiles) was found by the geochemical working group (Wefer \& Schulz, 1993), which is also involved in the SFB. In contrast to Station 1721, Station 1711 
FDA hydrolysis [nmol FDA/mi*h]

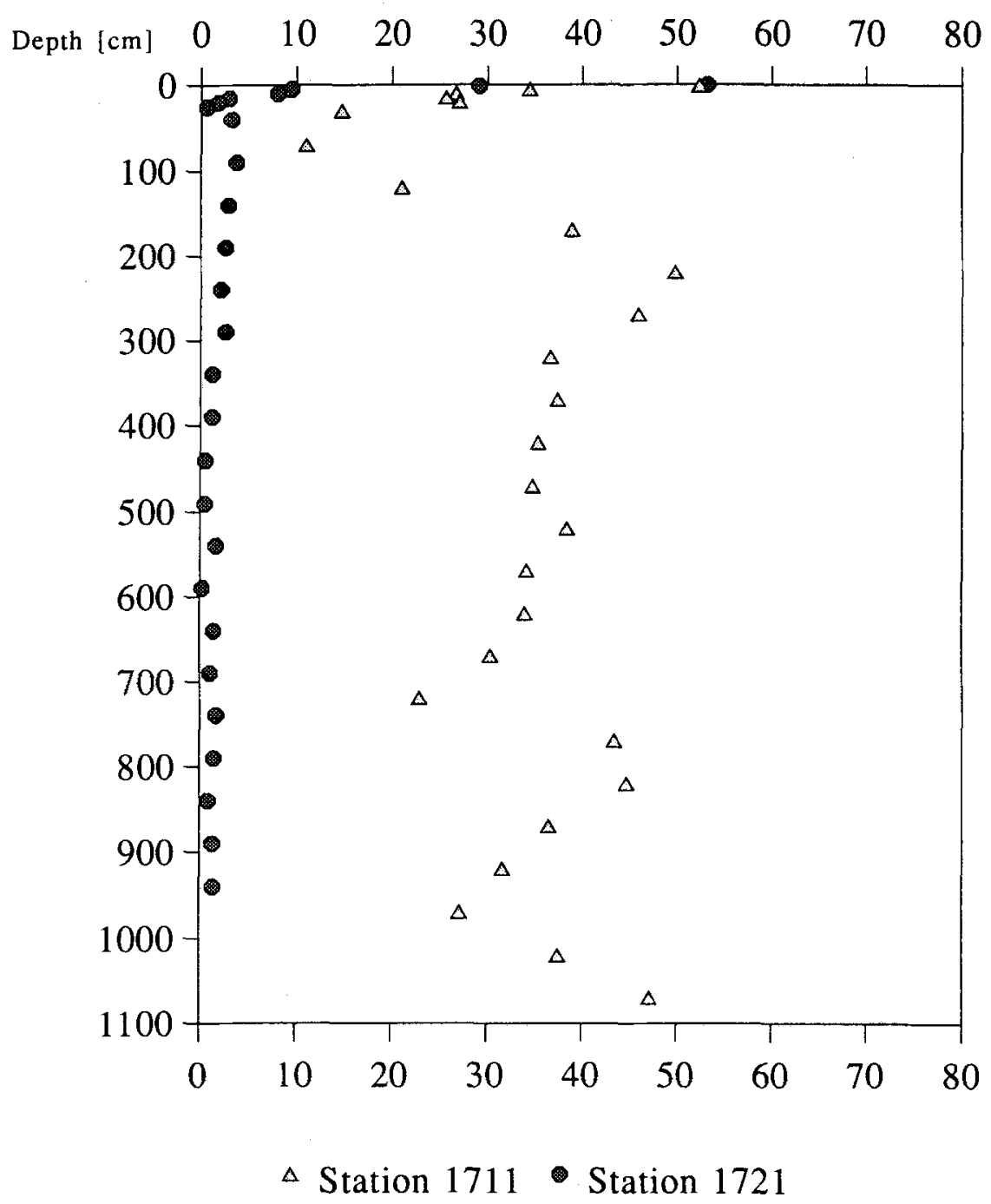

Fig. 2. Esterase activities in sediment samples from the Stations GeoB 1711 and 1721; water depth $2000 \mathrm{~m}$ and $3000 \mathrm{~m}$, carbonate/clay sludge and carbonate sludge, respectively

shows high enzymatic activities at greater depths. Between 1 and $70 \mathrm{~cm}$ the esterase activity decreases, but at $2 \mathrm{~m}$ sediment depth the activity level prevailing at the surface is nearly attained. In the depth range of $2 \mathrm{~m}$, the geochemical working group found gradient changes in regard to alkalinity and phosphate content of the pore water (ibid.). These are obviously caused by microorganisms. The high level of microbial activity at greater depths is accompanied by high sulphide concentrations in the pore water, especially at $10 \mathrm{~m}$ sediment depth (nearly $3000 \mu \mathrm{mol} / \mathrm{l}$ ) (ibid.), indicating sulfate reduc- 
tion. At this depth, a gradient change in regard to alkalinity, high ammonium concentrations in the pore water and a release of phosphate into the pore water were also found (ibid.). Derived from these findings, and the high enzymatic hydrolysis capacities from 2-11 $\mathrm{m}$ at Station 1711, we expect a high level of anaerobic decomposition of organic matter by microbial sulfate reduction as well as microbial fermentation.

The different depth profiles elucidate, moreover, that at Station 1711 there is more organic substance available for microbial degradation than at Station 1721. Both stations are located in the coastal upwelling area of the Benguela Coastal Current, which is

Resazurin reduct. [nmol resorufin/ml*h]

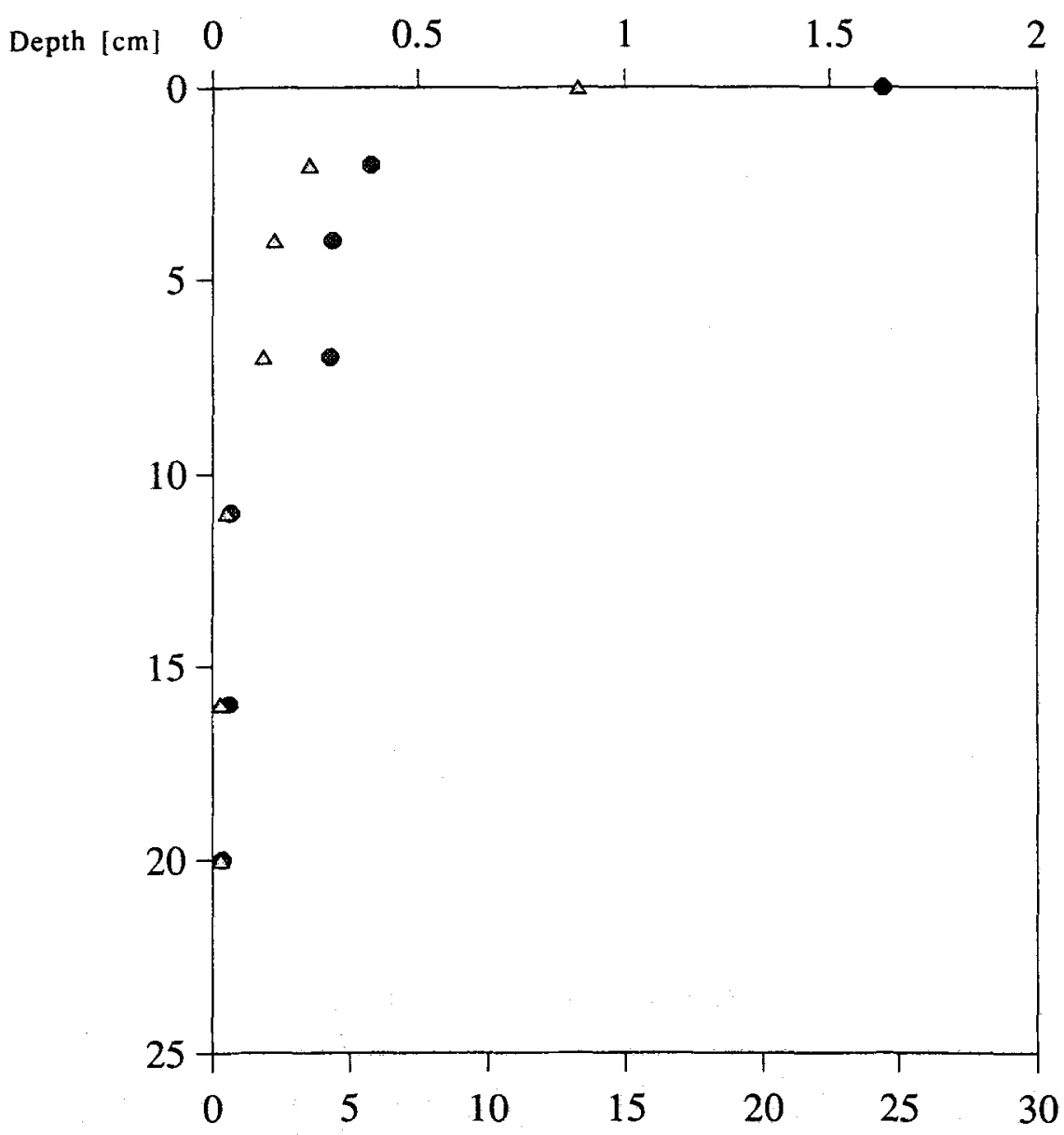

FDA hydrolysis [nmol FDA/ml*h]

\section{$\Delta$ Dehydrogenase Esterase}

Fig. 3. Dehydrogenase and esterase activities in sediment samples from Station GeoB 1726; water depth $1000 \mathrm{~m}$, foraminiferous sand 
influenced by the south-east trade winds. In the upwelling area cold, nutrient-rich water reaches the surface, effecting high total annual primary production rates of more than $100 \mathrm{~g} \mathrm{C} \mathrm{m}^{-2} \mathrm{yr}^{-1}$ (Berger, 1989). But while Station 1711 has a water depth of $2000 \mathrm{~m}$ and lies presently in the central part of the coastal upwelling area, Station 1721 has a water depth of $3000 \mathrm{~m}$ and is situated at the southern boundary of the coastal upwelling area (cf. Oberhänsli, 1991).

Figures 3-6 show depth profiles of esterase activities, together with dehydrogenase activities.

Resazurin reduct. [nmol resorufin $/ \mathrm{ml}^{*} \mathrm{~h}$ ]

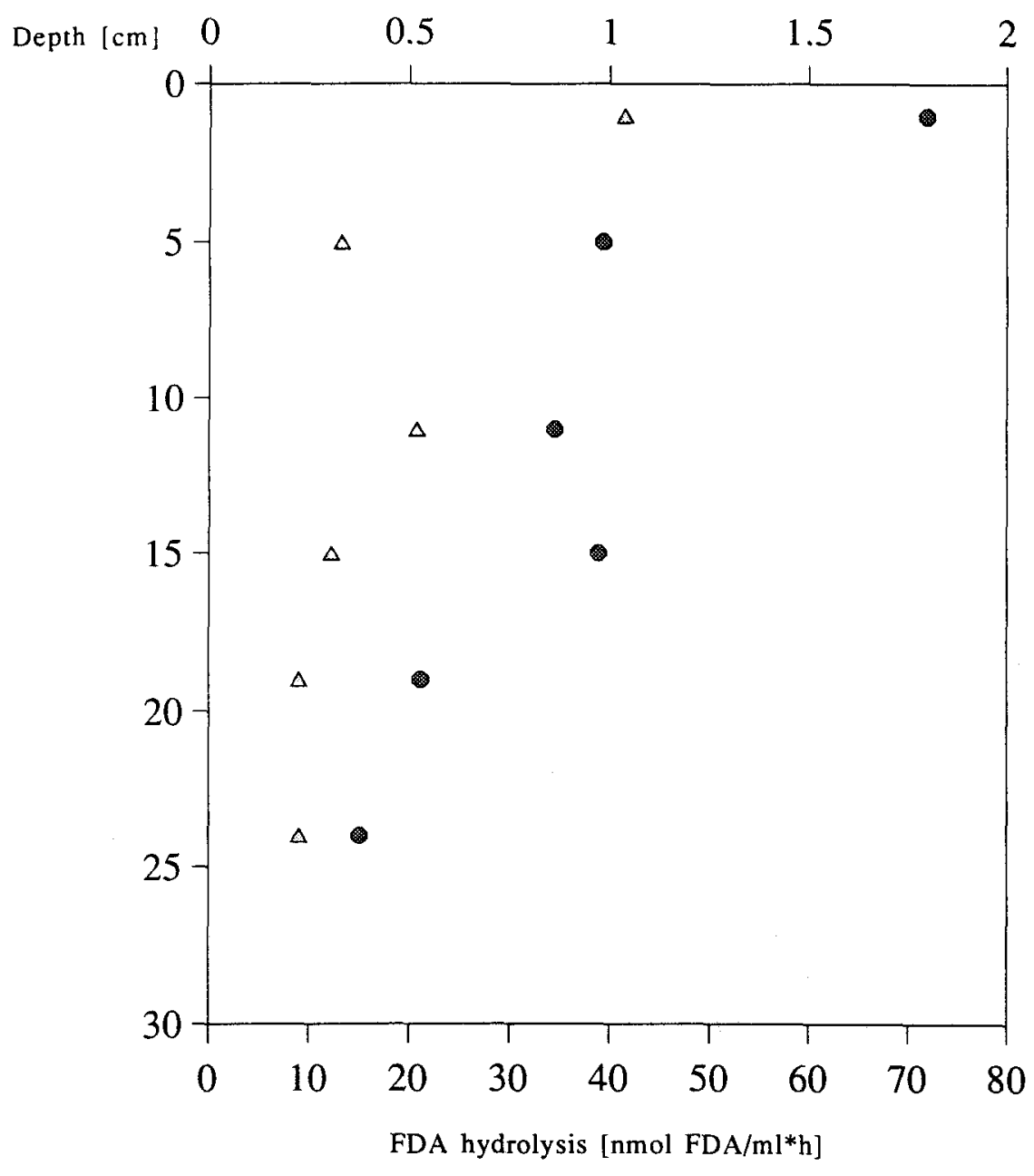

\section{$\triangle$ Dehydrogenase Esterase}

Fig. 4. Dehydrogenase and esterase activities in sediment samples from Station GeoB 1719; water depth $1000 \mathrm{~m}$, carbonate/clay sludge 
In Figures $3-5$, both activity parameters show a similar trend. The same is valid for Station 1721 up to a sediment depth of about $90 \mathrm{~cm}$ (Fig. 6). In these areas a positive linear correlation of $r=0.846$ between both enzyme activities was determined. Because dehydrogenase are thought to be exclusively intracellular enzymes (within live cells) (Skujins, 1975, 1978), we believe these results indicate that in the upper sediment layers of the Stations 1719,1721, 1724 and 1726 the esterase activities are also largely a result of enzymes of proliferating organisms, in contrast to accumulated enzymes (cf. Burns, 1982).

Below $90 \mathrm{~cm}$ (Fig. 6) the profiles for dehydrogenase and esterase activities differ very

Resazurin reduct. [nmol resorufin $/ \mathrm{ml}^{*} \mathrm{~h}$ ]

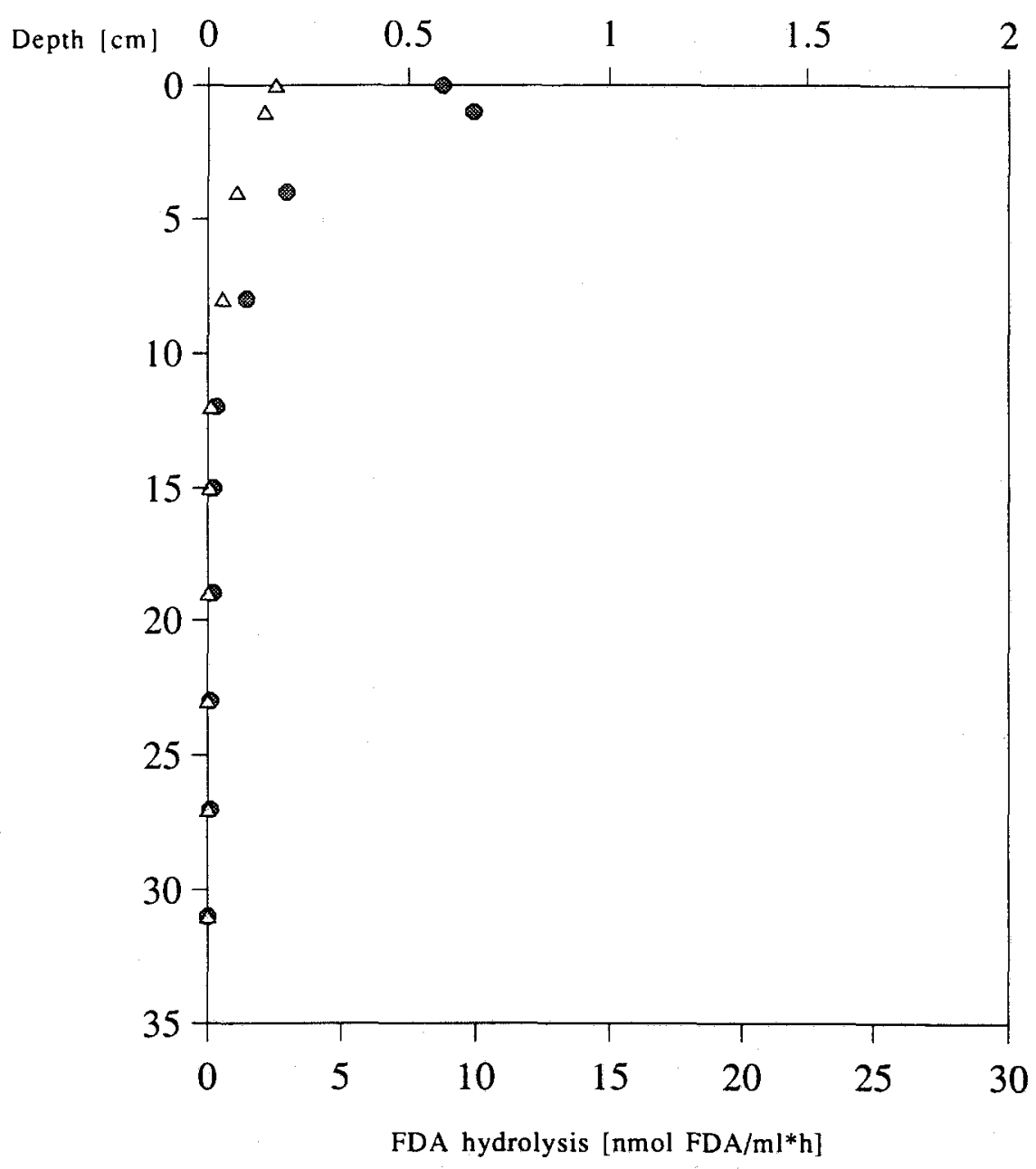

\section{$\Delta$ Dehydrogenase $\bullet$ Esterase}

Fig. 5. Dehydrogenase and esterase activities in sediment samples from Station GeoB 1724: water depth $5100 \mathrm{~m}$, deep-sea clay 
much from one another. In contrast to the esterase activities, the dehydrogenase activities rise with increasing sediment depth. This would mean that the organic material is largely oxidized in the deeper sediment layers and not in the upper ones. Nevertheless, this conclusion is supported neither by the esterase activities nor chemical data (compare Wefer \& Schulz, 1993). It was found that in the areas with high correspondence of both activity parameters, there were high $E_{h}$-values $(>200 \mathrm{mv})$, but in the areas with low correspondence the $E_{h}$-values were below $200 \mathrm{mv}$ (up to $-88 \mathrm{mv}$ ). According to Thalmann (1967), triphenyltetrazolium chloride-reduction as a measure for dehydrogenase

Resazurin reduct. [nmol resorufin $/ \mathrm{m}]^{*} \mathrm{~h}$ ]

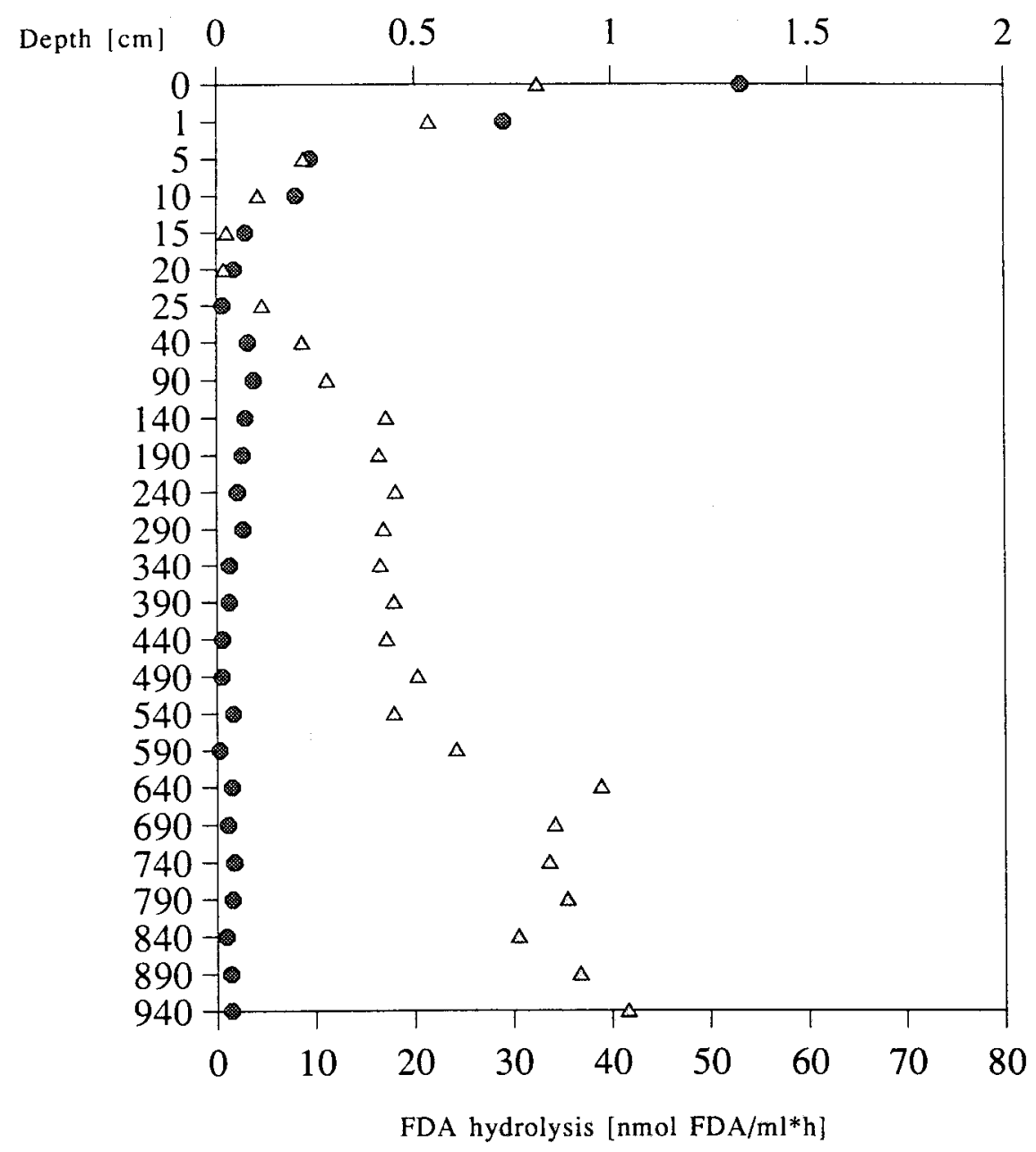

\section{$\triangle$ Dehydrogenase Esterase}

Fig. 6. Dehydrogenase and esterase activities in sediment samples from Station GeoB 1721; water depth $3000 \mathrm{~m}$, carbonate-sludge 
activity depends not only on the'enzyme concentration, but also, among other things, on the presence of alternative electron acceptors and abiotic reducing compounds (e.g. $\mathrm{Fe}^{++}$- and sulphide-compounds, nascent hydrogen). Therefore one must assume that the biological resazurin reduction cannot be determined under suboxic or anoxic conditions with the method described above, probably because an appropriate separation between chemical and biological reduction is not possible.

Table 2. Comparison of enzymatic activities, $\mathrm{C}_{\mathrm{org}}{ }^{-}$and $\mathrm{N}_{\text {total }}$-content in the surface sediments (samples from box-corers, $1 \mathrm{~cm}$ depth)

\begin{tabular}{llccccc|}
$\begin{array}{l}\text { Station } \\
\text { GeoB }\end{array}$ & $\mathrm{cm}$ & $\begin{array}{c}\mathrm{Wd} \\
\mathrm{m}\end{array}$ & $\begin{array}{c}\mathrm{C}_{\text {org }} \\
\%\end{array}$ & $\begin{array}{c}\mathrm{N}_{\text {total }} \\
\%\end{array}$ & $\begin{array}{c}\text { Esterase activities } \\
\text { nmol FDA ml } \mathrm{h}^{-1} \mathrm{~h}^{-1}\end{array}$ & $\begin{array}{c}\text { Dehydrogenase activities } \\
\text { nmol resorufin } \mathrm{ml}^{-1} \mathrm{~h}^{-1}\end{array}$ \\
\hline $1719-5$ & 1 & 1024 & 2.41 & 0.32 & 72 & 1.04 \\
$1711-5$ & 1 & 1964 & 1.74 & 0.24 & 52 & 0.85 \\
$1724-4$ & 1 & 5102 & 0.51 & 0.1 & 10 & 0.14 \\
$1721-4$ & 1 & 3079 & 0.38 & 0.07 & 29 & 0.54 \\
$1726-2$ & 1 & 1006 & 0.1 & 0.02 & 6 & 0.24 \\
C- and N-data (unpubl.) from P. Müller, FB Geowissenschaften, Universität Bremen \\
Wd = water depth \\
$\%$ as weight percent of the saltfree dry matter \\
\end{tabular}

Comparing the enzymatic activities at the sediment surface of all stations $(1 \mathrm{~cm}$ depth; samples from box-corers) with each other, the following decreasing order can be determined: $1719,1711,1721$ and, depending which activity is compared, Station 1724 or 1726 (compare Table 2). Furthermore, a relation to the organic carbon and total nitrogen content of the sediments can be stated. The enzymatic activities in the surface sediments rise with increasing $\mathrm{C}$ - and $\mathrm{N}$-content, with the exception of Station 1721. But it should be noted that besides the quantity, the quality or availability of organic matter reaching the sea-floor also determines decomposition rates.

Acknowledgements. We thank L.-A. Meyer-Reil and M. Köster for their helpful advice concerning the work on board a research vessel and the test for FDA hydrolysis.

\section{LITERATURE CITED}

Alef, K., 1991. Methodenhandbuch Bodenmikrobiologie - Aktivitäten, Biomasse, Differenzierung. Ecomed, Landsberg, $284 \mathrm{pp.}$

Berger, W. H., 1989. Global maps of ocean productivity. In: Productivity of the ocean: present and past. Ed. by W. H. Berger, V. S. Smetacek \& G. Wefer. Wiley, Chichester, 429-455.

Burns, R. G., 1982. Enzyme activity in soil - location and a possible role in microbial ecology. - Soil Biol. Biochem. 14, 423-427.

Chrzanowski, T. H., Crotty, R. D., Hubbard, J. G. \& Welch, R. P., 1984. Applicability of the fluorescein diacetate method of detecting active bacteria in freshwater. - Microb. Ecol. 10, 179-185.

Ewald, M., Herrmann, K. \& Weidmann, M., 1987. Kurzzeittest für die Bestimmung der Dehy drogenaseaktivität von Belebtschlämmen. - Vom Wasser 68, 165-175. 
Ewald, M., 1989. Vergleich zweier Methoden zur Bestimmung der Dehydrogenasenaktivität von Belebtschlämmen. - Z. Wasser-Abwasser-Forsch. 22, 28-32.

Guilbault, G. G. \& Kramer, D. N., 1964. New direct fluorometric method for measuring dehydrogenase activity. - Analyt. Chem. 36, 2497-2498.

Guilbault, G. G. \& Kramer, D. N., 1965. Fluorometric procedure for measuring the activity of dehydrogenases. - Analyt. Chem. 37, 1219-1221.

Guilbault, G. G. \& Kramer, D. N., 1966. Lipolysis of fluorescein and eosin esters - kinetics of hydrolysis. - Analyt. Biochem. 14, 28-40.

Holzapfel-Pschorn, A., Obst, U. \& Haberer, K., 1987. Sensitive methods for the determining of microbial activities in water samples using fluorigenic substrates. - Fresenius Z. analyt. Chem. $327,521-523$.

Köster, M., Jensen, P. \& Meyer-Reil, L.-A., 1991. Hydrolytic activities of organisms and biogenic structures in deep-sea sediments. In: Microbial enzymes in aquatic environments. Ed. by R. J. Chrost. Springer, New York, 298-310.

Köster, M., 1992. Mikrobieller Abbau von organischem Material an Grenzzonen - erläutert an Beispielen von Sedimenten der Nordsee und des Europäischen Nordmeeres. Diss., Univ. Kiel, 148 pp.

Kuemmerlin, R., 1982. Technical note: resazurin test for microbiological control of deep-frozen shrimps. - J. Food Technol. 17, 513-515.

Ladd, J. N., 1978. Origin and range of enzymes in soil. In: Soil enzymes. Ed. by R. G. Burns. Acad. Press, London, 51-96.

Liu, D., 1981. A rapid biochemical test for measuring chemical toxicity. - Bull. environ. Contam. Toxicol. 26, 145-149.

Liu, D., 1983. Resazurin reduction method for activated sludge process control. - Environ. Sci. Technol. 17, 407-411.

Liu, D. \& Strachan, W. M. J., 1979. Characterization of microbial activity in sediment by resazurin reduction. - Ergebn. Limnol. 12, 24-31.

Meyer-Reil, L.-A., 1991. Ecological aspects of enzymatic activity in marine sediments. In: Microbial enzymes in aquatic environments. Ed. by R. J. Chrost. Springer, New York, 84-95.

Oberhänsli, H., 1991. Upwelling signals at the northeastern Walvis Ridge during the past 500,000 years. - Paleoceanogr. 6, 53-71.

Peroni C. \& Rossi, G., 1986. Determination of microbial activity in marine sediments by resazurin reduction. - Chem. Ecol. 2, 205-218.

Reddy, Y. M., Karunasagar, I., Karunasagar, I. \& Udupa, K. S., 1990. The resazurin test for estimating bacteriological quality of shrimps. - Asian Fish. Sci. 3, 263-267.

Schnürer, J. \& Rosswall, T., 1982. Fluorescein diacetate hydrolysis as a measure of total microbial activity in soil and litter. - Appl. environ. Microbiol. 43, 1256-1261.

Skujins, J., 1975. Extracellular enzymes in soil. - Crit. Rev. Microbiol. 4, 383-421.

Skujins, J., 1978. History of abiotic soil enzyme research. In: Soil enzymes. Ed. by R. G. Burns. Acad. Press, London, 1-49.

Swisher, R. \& Carroll, G. C., 1980. Fluorescein diacetate hydrolysis as an estimator of microbial biomass on coniferous needle surfaces. - Microb. Ecol. 6, 217-226.

Thalmann, A., 1967. Über die mikrobielle Aktivität und ihre Beziehungen zu Fruchtbarkeitsmerkmalen einiger Ackerböden unter besonderer Berücksichtigung der Dehydrogenaseaktivität (TTC-Reduktion). Diss. Univ. Gießen, $227 \mathrm{pp.}$

Wefer, G. \& Schulz, H. D., 1993. Ostatlantik 91/92 - Expedition, Reise Nr. 20, M 20/1 und M 20/2, 18. November 1991 - 3. Februar 1992. - Meteor-Ber. 93-2, 1-248.

Wetzel, A., 1981. Ökologische und stratigraphische Bedeutung biogener Gefüge in quartären Sedimenten am NW-afrikanischen Kontinentalrand. - Meteor Forsch.-Ergebn. (C) 34, 1-47. 